\title{
Pathobiology
}

\section{Next-Generation Sequencing}

\author{
Guest Editor
}

Gerald Hoefler, Graz

14 figures, 9 in color, and 9 tables, 2018 


\section{Disclosure Statement Guest Editor The Guest Editor declares he has no conflicts of interest.}

\section{S. Karger}

Medical and Scientific Publishers Basel $\cdot$ Freiburg $\cdot$ Paris $\cdot$ London . New York · Chennai · New Delhi . Bangkok $\cdot$ Beijing $\cdot$ Shanghai $\cdot$ Tokyo . Kuala Lumpur $\cdot$ Singapore $\cdot$ Sydney

\section{Disclaimer}

The statements, opinions and data contained in this publication are solely those of the individual authors and contributors and not of the publisher and the editor(s). The appearance of advertisements in the journal is not a warranty, endorsement, or approval of the products or services advertised or of their effectiveness, quality or safety. The publisher and the editor(s) disclaim responsibility for any injury to persons or property resulting from any ideas, methods, instructions or products referred to in the content or advertisements.

Drug Dosage

The authors and the publisher have exerted every effort to ensure that drug selection and dosage set forth in this text are in accord with current recommendations and practice at the time of publication. However, in view of ongoing research, changes in government regulations, and the constant flow of information relating to drug therapy and drug reactions, the reader is urged to check the package insert for each drug for any change in indications and dosage and for added warnings and precautions. This is particularly important when the recommended agent is a new and/or infrequently employed drug.
All rights reserved

No part of this publication may be translated into other languages, reproduced or utilized in any form or by any means, electronic or mechanical, including photocopying, recording microcopying, or by any information storage and retrieval system, without permission in writing from the publisher or, in the case of photocopying, direct payment of a specified fee to the Copyright Clearance Center (see 'General Information')

(C) Copyright 2018 by S. Karger AG,

P.O. Box, CH-4009 Basel (Switzerland)

Printed on acid-free and non-aging paper (ISO 9706)

ISBN 978-3-318-06332-5

e-ISBN 978-3-318-06333-2

\section{KARGER}




\section{Contents}

Editorial

289 Next-Generation Sequencing in Diagnostics and Clinical Research Hoefler, G. (Graz)

Review

292 Next-Generation Sequencing in Diagnostic Pathology Ilyas, M. (Nottingham)

306 Genetic Profiling of Cancers of the Digestive System: Biological Insights and Clinical Implications

Stenzinger, A. (Heidelberg); Weichert, W. (Munich)

Next Generation Sequencing

323 Role of Next-Generation Sequencing as a Diagnostic Tool for the Evaluation of Bone and Soft-Tissue Tumors

Szurian, K.; Kashofer, K.; Liegl-Atzwanger, B. (Graz)

Original Paper

339 Next-Generation Sequencing in Gynaecological Tumours: The Prognostic and Predictive Value of the Most Common Mutations Found in Ovarian, Endometrial, and Cervical Tumours: Literature Review and the University Medical Centre Utrecht Next-Generation Sequencing Data

van Winkel, E.; de Leng, W.W.J.; Witteveen, P.O.; Jonges, T.; Willems, S.M.; Langenberg, M.H.G. (Utrecht)

351 Author Index/Subject Index

352 Acknowledgement to Reviewers 
